\title{
Associations of egg production with the major histocompatibility complex in broiler breeder hens
}

\author{
Becky Jean Tarleton \\ West Virginia University
}

Follow this and additional works at: https://researchrepository.wvu.edu/etd

\section{Recommended Citation}

Tarleton, Becky Jean, "Associations of egg production with the major histocompatibility complex in broiler breeder hens" (1999). Graduate Theses, Dissertations, and Problem Reports. 992.

https://researchrepository.wvu.edu/etd/992

This Thesis is protected by copyright and/or related rights. It has been brought to you by the The Research Repository @ WVU with permission from the rights-holder(s). You are free to use this Thesis in any way that is permitted by the copyright and related rights legislation that applies to your use. For other uses you must obtain permission from the rights-holder(s) directly, unless additional rights are indicated by a Creative Commons license in the record and/ or on the work itself. This Thesis has been accepted for inclusion in WVU Graduate Theses, Dissertations, and Problem Reports collection by an authorized administrator of The Research Repository @ WVU. For more information, please contact researchrepository@mail.wvu.edu. 
Associations of Egg Production With the Major Histocompatibility Complex in Broiler Breeder Hens

Becky Jean Tarleton, B.S.

Thesis submitted to the Graduate Faculty of the College of Agriculture and Forestry at West Virginia University in Partial Fulfillment of the Requirements

for the Degree of

Master of Science

in

Reproductive Physiology

Robert A. Dailey, Ph.D., Chair

E. Keith Inskeep, Ph.D.

Paul E. Lewis, Ph.D.

Division of Animal and Veterinary Sciences

Morgantown

West Virginia

1999

Keywords: Major Histocompatibility Complex, Broiler Breeder Hens, Egg Production 


\section{ABSTRACT \\ Associations of Egg Production With the Major Histocompatibility Complex in Broiler Breeder Hens}

\section{Becky Jean Tarleton, B.S.}

This study documents effects of the major histocompatibility complex (MHC) on reproductive traits in a flock of Cobb X Cobb broiler breeder hens. The objective was to determine if the MHC affects reproduction of non-congenic broiler breeder hens. Genomic DNA was isolated from 35 hens. Restriction fragment length polymorphism (RFLP) analysis was performed on each sample, using a chicken class II MHC probe (Xu et al. 1989.) Restriction endonuclease digestion using PvuII resulted in polymorphisms in all birds. Five polymorphic bands were identified. The largest bands, $7.5 \mathrm{~kb}$ and $5.4 \mathrm{~kb}$, were present in one and four hens respectively. The $4.25 \mathrm{~kb}$ and $3.4 \mathrm{~kb}$ bands were present in 34 and 35 of the hens. The fifth band, $2.4 \mathrm{~kb}$, was observed in only 13 of the animals. Five putative genotypes were observed, based on the combination of RFLP pattern observed. The two most frequent putative genotypes differed only in the absence $(A ; n=17)$ or presence $(B ; n=13)$ of the fifth band. Egg production records for these two groups were subjected to statistical analyses. Total eggs produced and number of eggs produced during a 45-week fertility study were both significantly higher for hens with genotype A. Hens with genotype B had longer pauses between ovipositions. This study provides evidence, in a non-congenic population of broiler breeder hens, that there are associations of egg production with the MHC. 


\section{ACKNOWLEDGMENTS}

The author would like to thank many individuals for their contributions to her professional and personal development. First, thanks to Drs. Robert Dailey, Keith Inskeep, and Paul Lewis for their guidance, prodding, challenges, and patience. I am grateful and forever indebted to you for the opportunities I had and the lessons I learned at West Virginia University. Thanks also go to Dr. Steve Lerner for an idea, and to Dr. Susan Lamont and Mike Kaiser for valuable help and consultations. My fellow graduate students, especially Carie Bartley, also deserve recognition for their help and friendship; thanks are extended to Drs. Nasim Ahmad, Chi-Sheng Yang, David Wright, and to Jim Pritchard, William Buford, Carey Boyce, Jeff McGowan, and Rob Taft. I was proud to work with many people who

offered their friendship along with labor: Susan Slider, Fred Roe, and Gordon Adams in particular. Most importantly, the author wishes to thank her family for patience, inspiration, support, and love. Without them this endeavor would never have been achievable, or completed. So a final thanks to Allen, Elaine, Cathy, and Mary Tarleton and Ron Muir. I appreciate and love you all. 


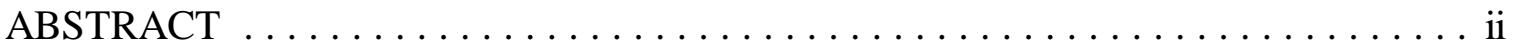

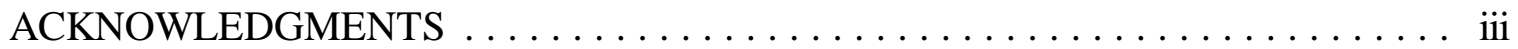

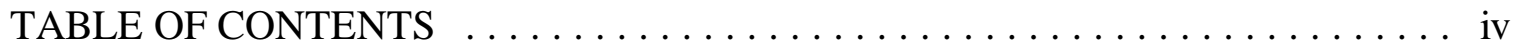

LIST OF TABLES AND FIGURES $\ldots \ldots \ldots \ldots \ldots \ldots \ldots \ldots \ldots \ldots \ldots$ vi

REVIEW OF LITERATURE $\ldots \ldots \ldots \ldots \ldots \ldots \ldots \ldots \ldots \ldots \ldots \ldots$

INTRODUCTION $\ldots \ldots \ldots \ldots \ldots \ldots \ldots \ldots \ldots \ldots \ldots \ldots \ldots \ldots \ldots$

DESCRIPTION OF THE MAJOR HISTOCOMPATIBILITY COMPLEX . . . . 2 EFFECTS OF THE MAJOR HISTOCOMPATIBILITY COMPLEX ON REPRODUCTION ............................. 5

HETEROZYGOSITY $\ldots \ldots \ldots \ldots \ldots \ldots \ldots \ldots \ldots \ldots \ldots \ldots$

SELECTION STUDIES $\ldots \ldots \ldots \ldots \ldots \ldots \ldots \ldots \ldots \ldots \ldots$

STATEMENT OF THE PROBLEM $\ldots \ldots \ldots \ldots \ldots \ldots \ldots \ldots \ldots \ldots \ldots \ldots \ldots$

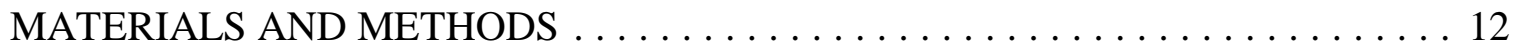




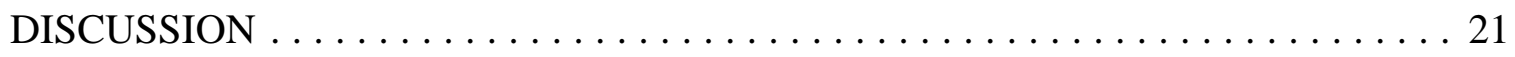

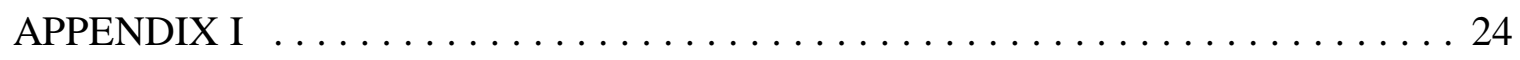

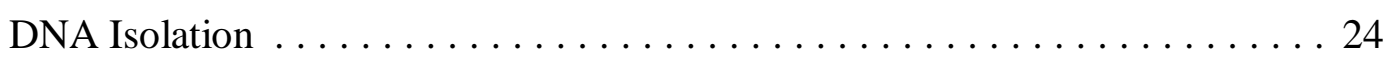

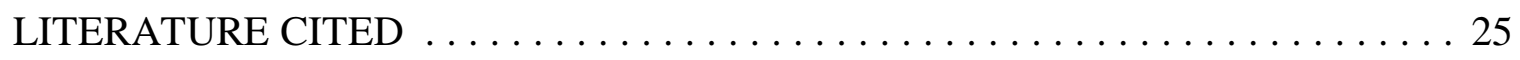

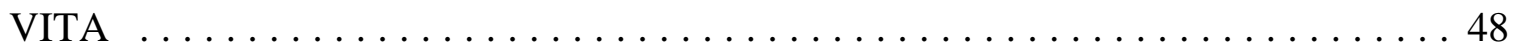




\section{LIST OF TABLES AND FIGURES}

TABLE 1. Restriction Fragment Polymorphism Analysis of the Major Histocompatibility Complex in Broiler Breeder Hens: Frequency of Bands Observed. . . . . . . . . 16

TABLE 2. Restriction Fragment Length Polymorphism Analysis of the Major Histocompatibility Complex in Broiler Breeder Hens: Observed Banding Patterns With A Class II Probe. . . . . . . . . . . . . . . . 17

TABLE 3. Summary of Egg Production by Broiler Breeder Hens Bearing Different Major Histocompatibility Complex Genotypes $\ldots \ldots \ldots \ldots \ldots \ldots \ldots$

FIGURE 1.Representative autoradiogram depicting results of RFLP analysis of broiler breeder genomic DNA digested with $P v u I I$ and hybridized with a chicken MHC Class II cDNA clone, as described in Materials and Methods. Five lanes representing the five (putative) genotypes are presented as listed across the top of the figure. Relative molecular mass of each band is given along the left (in kilobases; kb). . . . . 19

FIGURE 2. Plot of clutch length (replaced by rank) by pause length (replaced by rank) for broiler breeder hens differing in major histocompatibility complex genotype. 


\section{REVIEW OF LITERATURE}

\section{INTRODUCTION}

Genetic selection has been a practical method for improving animal production for many years. Before selection pressures can be instituted, one must identify the traits of interest. Reproductive performance is such a trait that is of major concern in the broiler breeder flock, particularly as measured by rate of lay, fertility, and hatchability of eggs. These variables can be quantified easily but the quantification of productivity of offspring requires 66 weeks for broiler breeder hens. Animal production can be improved faster if the genes responsible for these traits can be identified utilizing analysis of deoxyribonucleic acid. Genes, including those of the major histocompatibility complex (MHC) can now be relatively easily detected and analyzed using molecular biology techniques. Alleles of the MHC that correlate with productivity can be identified and, potentially, used as selection criteria in breeding decisions. The review of literature will describe briefly the chicken MHC and associations of reproductive performance with the chicken $\mathrm{MHC}$. 


\section{DESCRIPTION OF THE MAJOR HISTOCOMPATIBILITY COMPLEX}

"Histocompatibility genes can be defined as genes that encode cell surface structures that are polymorphic within a species and are sufficiently immunogenic to evoke a rejection reaction" Hansen et al. (1993). Histocompatibility genes are located in the genomic region called the major histocompatibility complex (MHC). The mouse $\mathrm{MHC}$, or $\mathrm{H} 2$, was the first MHC discovered (Gorer, 1936), followed by the chicken (B complex; Briles et al., 1950), and the human (HLA) MHC (J. Dausset 1958). Klein (1986) discussed the presence of an MHC in mammalian, avian, and some reptilian species. Recent workers have demonstrated an MHC in more species, including the turkey (Emara et al., 1992), nurse shark (Kasahara, et al., 1992), rainbow trout (Juul-Madsen et al., 1992), Atlantic salmon (Hordvik et al., 1993), zebrafish (Takeuchi, et al., 1995), Xenopus laevis (Sato et al., 1993), and the ringnecked pheasant (Jarvi and Briles, 1992 and Wittzell et al., 1994).

Briles et al. described the B complex in 1950. Two blood group systems, A and B, were identified. Each caused expression of antigens on erythrocytes and were produced by independently assorting alleles. D. G. Gilmour, working in England, recorded the identification of erythrocyte antigens from four inbred lines of white leghorn chickens maintained there (Gilmour, 1959). The antigen systems documented by Gilmour were the same as the systems that Briles and coworkers were studying in the United States.

The B antigen type became an identification and classification tool for many experiments. Schierman and Nordskog (1961) described an experiment in which tissue grafts were performed between chickens from an inbred White Leghorn line. Erythrocyte antigen 
types were determined by hemagglutination. Skin grafts were performed between birds with different A, B, D, and L alleles. Graft rejection did not correlate with A, D, or L type but was affected by B type. In 38 grafts the donor had at least one B antigen which the host animal did not, and 20 of these animals underwent a rejection within 14 days. This experiment established the B complex as the chicken MHC.

The chicken MHC has been the subject of several review articles. Chickens have 39 pairs of chromosomes; five pairs of macrochromosomes and 34 pairs of microchromosomes (Ohno 1961, Owen 1965, Klein 1986, Bloom et al. 1987, and Guillemot et al. 1989). Pink et al. (1977) proposed a model for the chicken MHC. They determined that the B complex has two regions comprised of three loci; the $\mathrm{B}-\mathrm{F} / \mathrm{B}-\mathrm{L}$ and $\mathrm{B}-\mathrm{G}$ regions. The $\mathrm{B}$ complex is linked to the nucleolus organizing region (NOR; Bloom and Bacon 1985, Bloom et al. 1987, Guillemot et al. 1989). Bloom and Bacon (1985) also determined that the B complex is located on the sixteenth largest microchromosome (reviewed by Lamont and Dietert 1990). The B-F and B-L loci correspond to mammalian class I and class II, respectively. Guillemot and Auffray (1989) described the cellular expression of MHC molecules in the chicken. Leukocytes and erythrocytes express B-F molecules. B-L antigens are expressed by B cells and macrophages (leukocyte subpopulations). B-G antigens (class IV), which do not have a mammalian homologue, are expressed by erythrocytes and thrombocytes (Kaufman and Salomonsen, 1992).

The structure and function of MHC antigens have been deduced from sequence analysis and crystallographic studies. The known structures were reviewed by Roitt et al. (1993). Class I molecules consist of a $45 \mathrm{kDa}$ heavy chain that is noncovalently associated 
with $\beta_{2}$-microglobulin. The molecules possess three extracellular domains $(\alpha 1, \alpha 2$, and $\alpha 3)$, a transmembrane domain, and an intracellular domain. Class I antigens serve to present cytosolic peptides to the T cells. The presented peptides are usually self-derived. Class II molecules exist as heterodimers of heavy ( $\alpha$; 30-34 kDa) and light ( $\beta ; 26-29 \mathrm{kDa})$ glycoprotein chains. They also have single transmembrane and intracellular regions. These antigens are responsible for the presentation of exogenous peptides to immune cells. Kaufman and Salomonsen (1992) speculated on the function of B-G antigens. They proposed that either "B-G molecules are recognized by $\mathrm{T}$ cells... recognize antigen... or are recognized by B cells."

Briles et al. (1993) identified a system that is related to the MHC but is encoded by an independent MHC-like locus. This work was performed in a three generation family of chickens. Restriction fragment length polymorphism (RFLP) mapping was performed and the new locus (designated restriction fragment pattern-Y, $R f p-Y$ ) was found to sort independently from the MHC. The restriction fragments produced by $R f p-y$ are detected with DNA probes for chicken B-F and B-L genes in hybridizations of DNA. Miller et al. (1994) performed an experiment to ascertain the homology between $R f p-y$ and B genes. The authors concluded that the "Rfp- $Y$ genes may represent a separate isotype of MHC class I genes."

Many methods exist for studying the B complex (reviewed by Lamont, 1993). These methods can be divided into two categories, serological and molecular. Serological protocols require incubation of blood fractions with alloantisera that cause hemagglutination when they encounter antigens. Alloantisera may be used that detect B-G and B-F or are specific to B-F antigens (Briles et al., 1982 and Briles and Briles, 1982). Monoclonal antibodies to B-G 
antigens also are available. Molecular methods are based on DNA. B complex genes have been cloned. Restriction fragment length polymorphism analysis of the chicken MHC depends on the availability of cDNA probes for the B complex. Restriction fragment length polymorphism analysis of the MHC has proven useful in determining differences among individuals (Lamont et al., 1987a and Lamont, 1993), as it allows for molecular detection of different alleles for the MHC genes within a defined population of birds. Andersson et al. (1987) used probes from the HLA to produce RFLP of chicken B complex. Since chicken probes were produced, numerous workers have used them to study the B complex. Shuman et al. (1993) and Heath et al. (1994) presented data on the development of assays and new probes for practical MHC typing. They are working to develop a colorimetric assay for B-F type that can be analyzed using a plate reader. Heath et al. (1994) reported the successful use of 7 probes in typing congenic and commercial strains of chickens, including both Leghorns and broilers.

\section{EFFECTS OF THE MAJOR HISTOCOMPATIBILITY COMPLEX ON REPRODUCTION}

Lerner and Finch (1991) reviewed literature detailing associations of the MHC with reproductive functions in many species. Numerous studies have demonstrated effects of the B complex on productivity traits.

\section{HETEROZYGOSITY}

Briles and coworkers published a series of abstracts (Briles, 1953, Briles et al. 1953, Briles 1954a, Briles 1954b, Briles and Krueger 1955, Krueger et al. 1956, Briles 1956a, Briles 1956b) detailing experiments performed in three lines of chickens at Texas A \& M 
University. Hens from three related Leghorn inbred lines were mated to either a rooster that was homozygous or a rooster that was heterozygous at the "B locus." Hatchability of eggs from matings to heterozygous males was $66.7 \%$, while matings to homozygous males resulted in $48.5 \%$ hatchability, a highly significant difference (Briles 1953). Heterozygous cockerel chicks from two lines (22 and 23) were heavier at nine weeks of age than homozygous cockerels (Briles et al. 1953). The heterosis effect on male body weight was not observed in the third line (24). Briles (1954a) combined the hatchability data reported in Briles (1953) with a second year's observations. The hatchabilities of embryos with "0, 50, 75, and 100 percent heterozygosity were $46,62,71$, and 78 percent, respectively." Heterozygous sires produced $15 \%$ higher hatchability than did homozygous sires (69\% and 54\%). Egg production was higher for heterozygotes than homozygotes in all three inbred lines (Briles 1954b). Briles and Krueger (1955) reported that hatchability of fertile eggs from matings expected to produce $50 \%$ heterozygotes was significantly higher than hatchability from matings expected to produce $100 \%$ homozygotes $(\mathrm{p}<0.01)$. Krueger et al. (1956) found evidence that progeny from B complex heterozygous sires had higher juvenile livability and egg production than progeny from homozygous sires. Briles (1957) concluded, on the basis of three seasons' production data, "that the $B$ blood group locus (or one or more loci very closely linked to it) is displaying overdominant gene action with regard to hen-day production." Briles (1957) confirmed the data of Briles et al. (1953) by demonstrating that heterozygous $\left(B^{2} B^{7}\right)$ cockerels and pullets, produced by matings between two inbred lines, were heavier than homozygous $\left(B^{7} B^{7}\right)$ siblings. This series of experiments led Briles et al. (1957) to conclude that there is some positive effect of heterozygosity at the B locus on 
reproductive traits.

Briles and Allen (1961) studied the effects of B genotype on production traits in seven commercial strains of Hy-Line chickens. They found that there was an effect of genotype on percent hen-day egg production in two white leghorn lines, $\mathrm{H} 1$ and $\mathrm{H} 3$, and one New Hampshire line, H8. This effect was attributed to a lower rate of lay by one of the homozygous classes in each line. Allen (1962) studied crosses of inbred chickens, New Hampshire and Rhode Island Red. He found that B locus affected hatchability and adult survival ( $\mathrm{p}$ <0.01). Morton et al. (1965) found that progeny B type affected embryonic mortality and hatchability in a Light Sussex strain of chicken.

Allen and Gilmour (1962) compared two heterozygous genotypes in 7047 crossbred white leghorn pullets. They calculated the mean of three percentage traits as a measure of overall fitness. The traits measured were: juvenile mortality, adult mortality, and egg production. B blood type was a significant source of variation in this estimate, with the $B^{2 l} B^{14}$ pullets performing better than the $B^{21} B^{13}$ pullets. These workers were able to show that the heterozygotic advantage demonstrated in previous experiments also occurred in non-inbred chickens. Heterozygosity at the B locus was preserved after generations of selection for different traits; egg production, egg weight, occurrence of a winter pause, shank length, crooked toes, or normal toes (Schultz and Briles, 1953). These data were from 12 inbred lines from the University of California. Eleven of the 12 lines exhibited the continued heterozygosity, supporting the theory that natural selection favors some general fitness which is conveyed by heterozygosity at the B locus.

Two studies point to the idea that heterozygosity of the B locus, alone, does not 
explain all of the effects of the chicken MHC on production traits. Gilmour and Morton (1970) found that genotypic associations varied with generation and environment in two sublines of a moderately inbred Light Sussex strain of birds. In 1973, additional evidence was produced by Nordskog et al. that the heterozygotic superiority seen earlier may have been dependent on the population's genetic makeup. They studied two lines of white leghorn chickens ( S1 and S2) developed by Iowa State University. These lines had been synthesized to have four $\mathrm{B}$ locus haplotypes each; $\mathrm{B}^{1}, \mathrm{~B}^{2}, \mathrm{~B}^{19}$, and $\mathrm{B}^{21}(\mathrm{~S} 1)$ and $\mathrm{B}^{13}, \mathrm{~B}^{14}, \mathrm{~B}^{19}$, and $\mathrm{B}^{21}$ (S2). They found that both mortality and egg production were negatively affected by the $\mathrm{B}^{1}$ haplotype in the S1 population. The $\mathrm{B}^{1}$ haplotype affected only mortality of the $\mathrm{S} 2$ birds. The homozygotic $\mathrm{B}^{1}$ class always had increased mortality and lower egg production in this study. This work confirmed the earlier finding by Briles and Allen (1961) that the $\mathrm{B}^{1}$ allele was associated with increased adult mortality. After this study, research was focused on the effects of specific haplotypes in specific populations.

\section{SELECTION STUDIES}

Simonsen et al. (1982) established a white leghorn base population from crossing seven commercial hybrids. The F2 progeny from these birds were placed in four countries and selected for egg number, egg weight, or an index of the two. Each location maintained control and selected lines. Ten haplotypes contributed $95 \%$ of the base population's gene pool. Selection for the reproductive traits, egg number, and egg weight resulted in a significant increase in the frequency of $\mathrm{B}^{15}$ genes and a concomitant decrease in the frequency of $\mathrm{B}^{19}$ genes. Gavora et al. (1986) compared haplotypes and production data from three selected strains: unselected control, high egg production, and Marek's disease and high egg 
production. Selection altered haplotype frequency relative to controls. The selected lines had higher egg weight, lower adult mortality, and earlier sexual maturity than the randombred controls. Enhanced production was associated with increases in the frequency of $\mathrm{B}^{21}$ and $\mathrm{B}^{2}$ haplotypes. Lamont et al. (1987) determined the B type of 1095 chicks from four sublines of two lines that had been selected for either a high ratio of egg mass to 32 week body weight or a high ratio of egg mass to feed consumption at 32 week of age. The sublines were either replicate selected or unselected controls. Birds were typed after 6 generations of selection. Two haplotypes $\left(\mathrm{B}^{2}\right.$ and $\left.\mathrm{B}^{13}\right)$ were present in over $75 \%$ of all birds. Selection increased the $B^{2}$ allele at the expense of the $B^{13}$ allele. Selection for egg mass relative to 32 wk body weight increased the $\mathrm{B}^{14}$ allele. In another study there were no B type associations with production traits in birds that had been selected for antibody response to sheep erythrocytes (Martin et al., 1990). The same group of researchers (Dunnington et al., 1992), using the same selected lines of birds, found that the MHC affected production in white leghorn chickens, dependent on the birds' genetic background.

Boa-Amponsem et al. (1992) utilized White Plymouth Rock chickens that were being selected for high and low juvenile body weight and subpopulations with relaxed selection. Selection had been practiced for 28 weeks, before the sublines were established. The workers recorded hen body weight at 4, 8 , and $38 \mathrm{wk}$ of age, age and body weight at first egg, percent of normal eggs laid, and percent normal hen-day egg production. No differences were observed in any of these traits due to B genotype.

Abplanalp et al. (1992) and Sato et al. (1992) published work performed in congenic and inbred white leghorn hens. Abplanalp et al. (1992) created 12 congenic lines of birds by 
backcrossing birds to achieve $98.4 \%$ identical genes in the birds. The birds utilized shared the background genome of University of California, Davis line 003. "Fertility, hatchability of fertile eggs, egg production, mortality to $40 \mathrm{wk}$ of age, 40 -wk egg weight, and 40 -wk body weight" were all determined for the 12 lines. MHC haplotype affected all of the traits studied except fertility. Sato et al. (1992) designed a study for comparison of different heterozygotes within a common partially congenic background. Egg production, egg weight, and viability to $40 \mathrm{wk}$ of age were all higher for heterozygotic hens than the average of their respective homozygotic parents. Some heterosis was observed for hatchability, but no general conclusion could be made for this trait. $\mathrm{B}^{2}$ heterozygotes exhibited heterosis for most traits studied.

Kim et al. (1989) studied effects of haplotype on reproduction in the Iowa State University S1 line of white leghorn chickens. Traits measured included: body weight at 8, 20, and 32 wk of age, age at first egg, egg production over the entire experimental period, egg production from 29-32 wk of age, and average egg weight. Of the traits studied, only average egg weight was affected by MHC genotype. Homozygous $\mathrm{B}^{19} \mathrm{~B}^{19}$ birds had higher egg weights than $\mathrm{B}^{1}$ homozygotes. All heterozygotic classes had egg weights ranging between the two homozygotic classes. 


\section{STATEMENT OF THE PROBLEM}

The effects of the major histocompatibility complex on reproduction have been studied since 1950 in a variety of animals. The majority of this work, in chickens, has been performed in white leghorns, or chickens used for production of table eggs. Broiler breeders are different chickens than white leghorns. They are the parental strains used to produce broiler chickens, used for meat. Thus, identification of traits that can produce quantifiable increases in production of offspring by the parental strains (broiler breeders) would lead to methods of selection for meat-type chickens. The broiler breeder MHC has not, to date, been examined. Therefore, the objectives of the present study were to: 1) determine if the MHC is polymorphic in broiler breeder hens and 2) determine if the MHC is associated with superior reproductive performance in broiler breeder hens. 


\section{MATERIALS AND METHODS}

Thirty-five Cobb X Cobb broiler breeder hens were raised using a conventional feed restriction program (Cobb Vantress growing guide). Birds were caged individually at 19 weeks of age and fed $150 \mathrm{~g}$ of a commercial breeder-layer ration daily. Egg production was monitored every 2 hours from 0800 h to 1600 h daily for 55 weeks, from 20 August, 1992 until 7 September, 1993. Hens were inseminated with fresh, pooled semen weekly, beginning at 36 wk of age (20 October, 1992), after which eggs were set weekly. Egg weight was determined at the time of collection, $10 \mathrm{~d}$ and $19 \mathrm{~d}$ of incubation. Fertility and hatchability (day 21 of incubation) of each egg was recorded. Blood (1 milliliter) was obtained from each hen via brachial venipuncture, mixed with EDTA, brought to the laboratory, and stored at $20^{\circ} \mathrm{C}$. Genomic deoxyribonucleic acid (DNA) was extracted (Appendix 1) from 50 microliters of frozen blood for each hen. After extraction, DNA was subjected to digestion with the restriction endonuclease $P v u I I$ overnight. Digested DNA ( $8 \mu \mathrm{g})$ was separated by electrophoresis for 20-24 h at 35 milliamps in a $0.8 \%$ agarose gel in single-strength TBE () containing $0.5 \mu \mathrm{g} / \mathrm{mL}$ ethidium bromide. Each gel was photographed to aid in estimating molecular weights of DNA fragments after hybridization. Electrophoresed DNA was transferred to a nylon membrane (Sambrook, et al. 1989), then fixed to the membrane by UV crosslinking (Stratalinker ${ }^{\circledR}$ UV crosslinker, Stratagene, La Jolla, CA.)

Membranes were probed using a chicken class II MHC subclone, CC-II-7-1 (Xu, et al. 1989.) Probe DNA (50 ng) was labeled with $\alpha^{32} \mathrm{P}-\mathrm{dCTP}$ by random priming. Thirty milliliters of hybridization solution $\left(0.263 \mathrm{M} \mathrm{Na}_{2} \mathrm{HPO}_{4}, 7 \%\right.$ sodium dodecyl sulfate, $1 \mathrm{mM}$ EDTA, and $1 \%$ bovine serum albumin) was heated to $65^{\circ} \mathrm{C}$ and added to a hybridization 
tube. The membranes (1-2 per labelling) were placed in the hybridization tubes and prehybridized at $65^{\circ} \mathrm{C}$ for 20 minutes, with constant rotation. Labeled probe was denatured by boiling for 5 minutes, then placed on ice. Denatured probe was mixed with one milliliter of hybridization solution and added to the hybridization tube, to result in $1 \mathrm{X}^{16} \mathrm{cpm}$ of probe per milliliter of hybridization solution. Hybridization was performed overnight. Washing solutions were warmed to $65^{\circ} \mathrm{C}$. Membranes were washed at $65^{\circ} \mathrm{C}$ in: 1) 0.263 $\mathrm{M} \mathrm{Na}_{2} \mathrm{HPO}_{4}, 1 \%$ SDS once for 15-30 min, 2) 2 X SSC, $0.1 \%$ SDS twice for 15-30 min each, and 3) 1 X SSC, $0.1 \%$ SDS twice for 15-30 min each. Radioactivity was monitored between each wash and washing was stopped when background was low. Membranes were wrapped in plastic wrap and exposed to X-ray film at $-80^{\circ} \mathrm{C}$ for seven days. Autoradiographs obtained were scored by two independent observers on an individual bird basis, for the presence or absence of the five highest molecular weight bands. Membranes were stripped by soaking in boiled $0.5 \%$ SDS and allowed to cool while shaking.

Statistical analyses were performed using the General Linear Models procedures of SAS. For statistical analyses, only hens in Genotypes A and B were compared, since the single difference between these groups was the presence of the $2.4 \mathrm{~kb}$ band in the Genotype B group. Total egg production (over 65 weeks), egg mass, 45 week egg production (during the time of insemination and setting of eggs), percent fertility, percent hatchability, average and maximum clutch lengths, and average and maximum pause lengths were analyzed for the effects of genotype (A vs B). For clutch length and pause length (in which data were not distributed normally), a Wilcoxon rank-sum test (non-parametric procedure) was used to analyze for differences due to genotype. 


\section{RESULTS}

Broiler breeder DNA digested with $P v u I I$ was polymorphic when probed with a chicken MHC class II probe. Representative images of hybridizations giving the 5 observed banding patterns are shown in Figure 1. Five bands were observed with the following molecular weights: 7.5, 5.4, 4.25, 3.4, and 2.4 kilobases $(\mathrm{kb})$. These bands occurred in 1, $4,34,35$, and 13 birds, respectively (Table 1). Frequency of occurrence of these banding patterns among the 35 broiler breeder hens studied is summarized in Table 2. Five patterns of polymorphism were observed, and they have been designated as (putative) Genotypes A, B, C, D, and E. The $2.4 \mathrm{~kb}$ band was present only in 13 of the 35 hens studied (Genotype B). The other 4 bands were in either the great majority ( 4.25 and $3.4 \mathrm{~kb}$ bands) or 1 or 3 birds (7.5 and $5.4 \mathrm{~kb}$ bands). The two major patterns observed (Genotype A, n=17; Genotype B, $\mathrm{n}=13$ ) only differed in one respect, the presence of the $2.4 \mathrm{~kb}$ band in hens with Genotype B. Thus, the analysis of reproductive traits was conducted using only these two groups, based on the presence or absence of the fifth $(2.4 \mathrm{~kb})$ band. Age at puberty (first oviposition) was not different between Genotypes A and B ( $p>.89)$. Egg production for the entire 55 week collection period (Table 3$)$ was affected ( $p>.11)$ by genotype. Egg mass ( $>>26)$, percent fertility of eggs set ( $p>.62)$, and percent hatchability of fertile eggs ( $p>.72)$ were not different between groups. Egg production during the $46 \mathrm{wk}$ setting period was significantly $(\mathrm{p}<0.01)$ affected by genotype; broiler breeder hens with the $2.4 \mathrm{~kb}$ band $(113+/-7.7)$ laid more eggs than hens without the $2.4 \mathrm{~kb}$ band $(82+/-8.8)$. Number of clutches was not affected by genotype (p>.57). When average pause lengths were ranked and the ranks analyzed using non-parametric tests, it was determined that the birds without the $2.4 \mathrm{~kb}$ band had longer 
pauses than the birds with the $2.4 \mathrm{~kb}$ band $(\mathrm{p}<.08)$. This is demonstrated graphically in Figure 2 , with the rank for clutch length plotted by the rank for pause length of hens with Genotypes A and B. The distribution of data is such that Genotype A values tend to be distributed in the left portion of the graph, indicating shorter pauses (days between clutches). Coincident with this is the distribution of Genotype A values in the upper portion of the graph relative to Genotype B values, indicating that Genotype A hens had longer clutches (sequence of eggs oviposited on consecutive days.) 
TABLE 1. Restriction Fragment Polymorphism Analysis of the Major Histocompatibility Complex in Broiler Breeder Hens: Frequency of Bands Observed.

\begin{tabular}{cc}
\hline Fragment Length $(\mathrm{kb})$ & Number $(\mathrm{n}=35)$ \\
\hline 7.5 & 1 \\
5.4 & 4 \\
4.25 & 34 \\
3.4 & 35 \\
2.4 & 13 \\
\hline
\end{tabular}


TABLE 2. Restriction Fragment Length Polymorphism Analysis of the Major Histocompatibility Complex in Broiler Breeder Hens: Observed Banding Patterns With A Class II Probe.*

\begin{tabular}{|c|c|c|c|c|c|c|}
\hline \multirow{2}{*}{$\begin{array}{c}\text { Number of } \\
\text { Hens }\end{array}$} & \multirow[b]{2}{*}{ Genotype } & \multicolumn{5}{|c|}{ Fragment Length (kb) } \\
\hline & & 7.5 & 5.4 & 4.25 & 3.4 & 2.4 \\
\hline 17 & $\mathrm{~A}$ & 0 & 0 & 1 & 1 & 0 \\
\hline 13 & B & 0 & 0 & 1 & 1 & 1 \\
\hline 1 & $\mathrm{C}$ & 0 & 0 & 1 & 1 & 0 \\
\hline 1 & $\mathrm{D}$ & 1 & 1 & 0 & 1 & 0 \\
\hline 3 & $\mathrm{E}$ & 0 & 1 & 1 & 1 & 0 \\
\hline
\end{tabular}

* If a band of the indicated length was detected in the group 1 is recorded, and 0 indicates that the band was absent in that group. 
TABLE 3. Summary of Egg Production by Broiler Breeder Hens Bearing Different Major Histocompatibility Complex Genotypes.

\begin{tabular}{lrr}
\hline Variable & Genotype A & Genotype B \\
\hline 65 Week Production (Number of Eggs) & $198 \pm 12^{\mathrm{c}}$ & $169 \pm 14^{\mathrm{d}}$ \\
Egg Mass (g) & $63.54 \pm 0.91$ & $65.15 \pm 1.04$ \\
45 Week Production (Number of Eggs) & $113 \pm 7.7^{\mathrm{a}}$ & $82 \pm 8.8^{\mathrm{b}}$ \\
Percent Fertility & $76.9 \pm 3.5$ & $79.6 \pm 4.1$ \\
Percent Hatchability & $61.0 \pm 4.0$ & $63.2 \pm 4.6$ \\
Average Clutch Length (Days) & $2.0 \pm 0.1$ & $1.9 \pm 0.1$ \\
Maximum Clutch Length (Days) & $7.8 \pm 0.7$ & $6.5 \pm 0.7$ \\
Average Pause Length (Days) & $2.1 \pm 0.2$ & $2.3 \pm 0.2$ \\
Maximum Pause Length (Days) & $22.2 \pm 5.2^{\mathrm{c}}$ & $35.2 \pm 5.9^{\mathrm{d}}$ \\
\hline
\end{tabular}

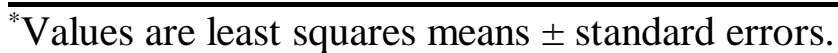

${ }^{a}$, bumbers within a row with different superscripts differ $(\mathrm{p}<.01)$.

${ }^{c,}$ Numbers within a row with different superscripts differ $(\mathrm{p}<.11)$. 


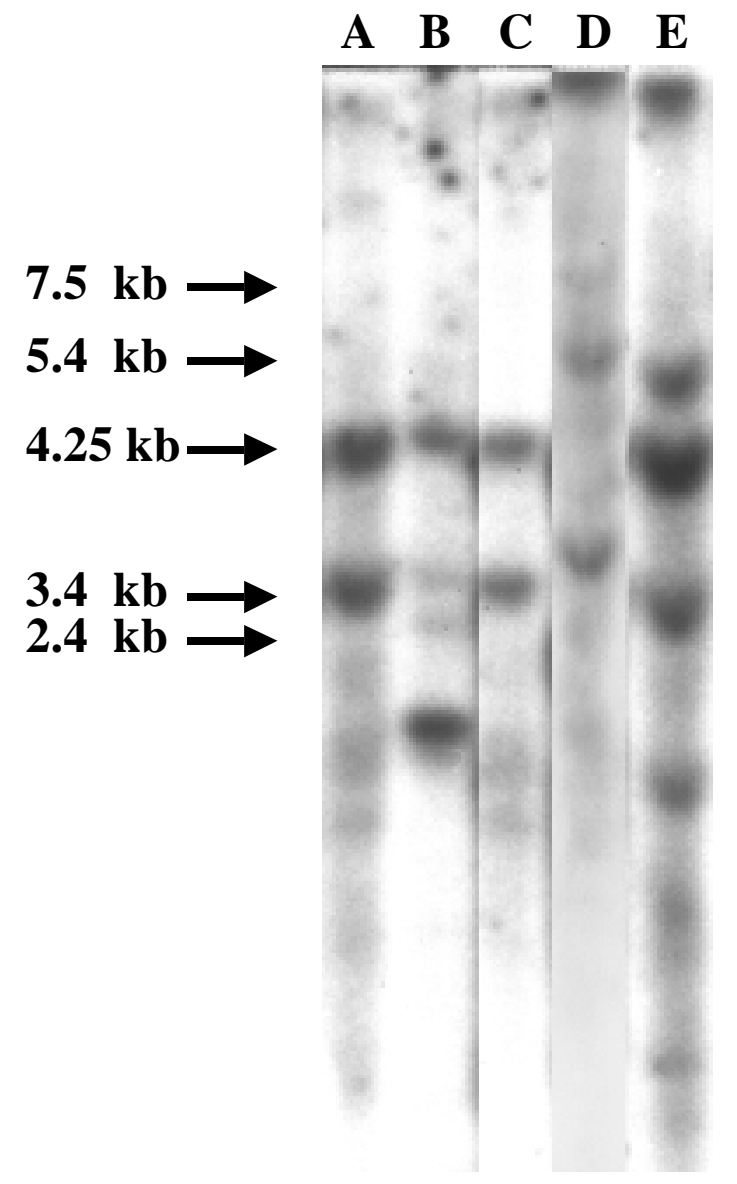

FIGURE 1.Representative autoradiogram depicting results of RFLP analysis of broiler breeder genomic DNA digested with PvuII and hybridized with a chicken MHC Class II cDNA clone, as described in Materials and Methods. Five lanes representing the five (putative) genotypes are presented as listed across the top of the figure. Relative molecular mass of each band is given along the left (in kilobases; kb). 


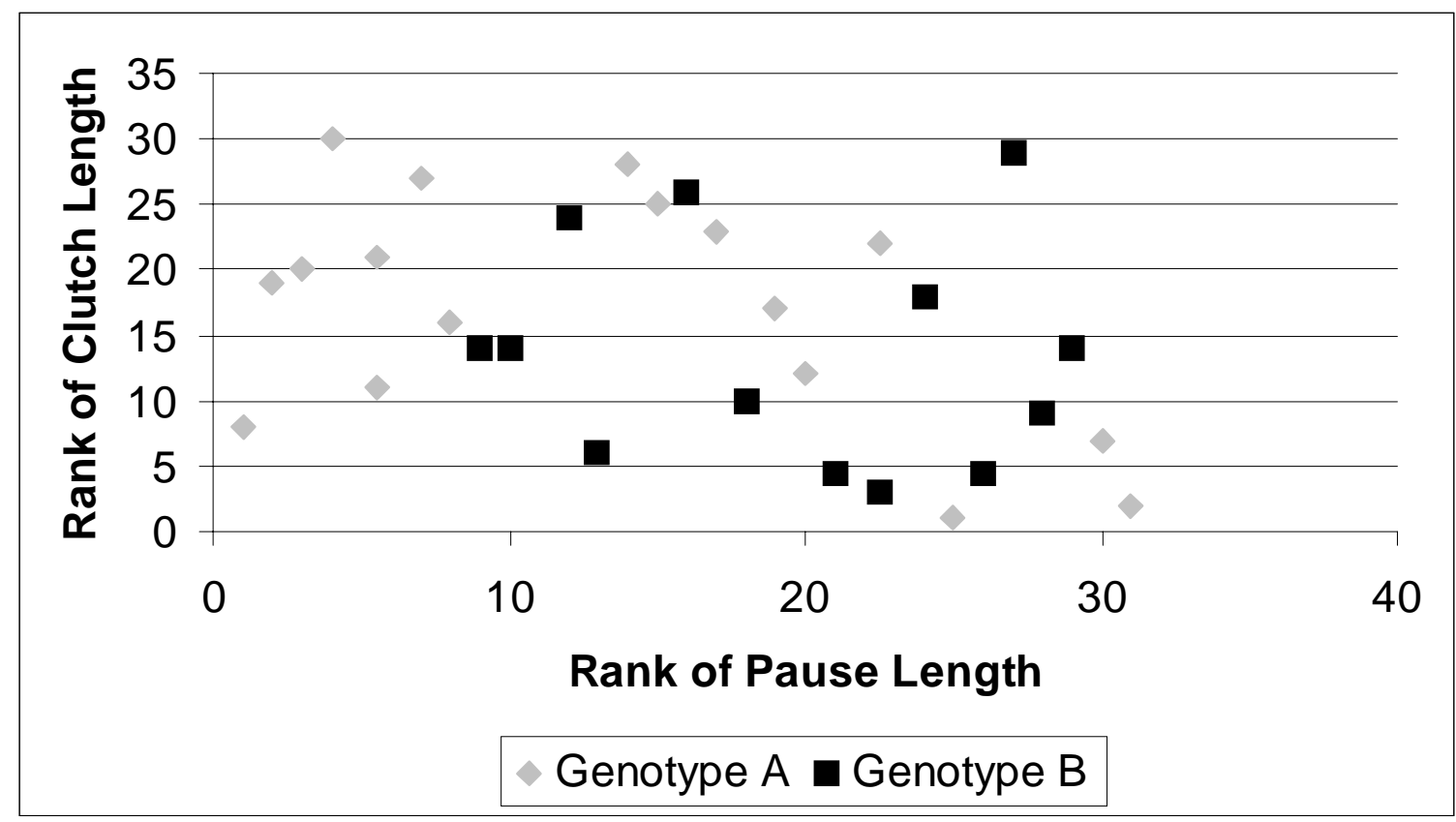

FIGURE 2. Plot of clutch length (replaced by rank) by pause length (replaced by rank) for broiler breeder hens differing in major histocompatibility complex genotype. Using the Wilcoxon rank-sum test for two samples, it was determined that hens with Genotype A (2.4 $\mathrm{kb}$ band absent) had longer pause periods between clutches than those hens with Genotype B (2.4 kb band present) at $\mathrm{p}<.05$. 


\section{DISCUSSION}

The broiler breeder MHC is polymorphic, when examined by Class II RFLP mapping. This is consistent with other work performed in white leghorn birds (Chausse et al., 1989 and Lamont et al., 1990). Lamont et al. (1990) used Class I and Class II probes to analyze DNA from congenic birds and demonstrated polymorphisms of both loci. Class IV polymorphisms were observed via RFLP mapping by Miller et al. (1988) and Uni et al. (1993). Emara et al. (1992) found that the turkey MHC exhibited Class II polymorphisms, which were further characterized by Zhu et al. (1995). Wittzell et al. (1994) described three MHC Class II haplotypes in the ring-necked pheasant utilizing RFLP. Thus, the present finding of polymorphisms is not surprising, but expands our knowledge of polymorphisms in different types of birds.

Neither frequency of bands observed with the Class II probe utilized (CCII-7-1; Xu et al., 1989), or banding patterns observed, can be used to assign any known haplotype, since we do not have parent, sire, or offspring genotype data. Parental and offspring information must be obtained and compared to the known generation in order to determine the inheritance of this locus. There are ongoing efforts among avian immunogeneticists to establish an international reference standard for RFLP genotypes as they relate to known serological haplotypes. The serological haplotypes were catalogued by Briles et al. (1982) and by Briles and Briles (1989). The reference standards are based primarily on white leghorn chickens. More detailed analysis of the broiler breeder MHC must be performed before the results of this study can be extrapolated to the established haplotypes or to the entire population of broiler breeder hens. 
The banding patterns observed in the present study represent five genotypes (A-E). The patterns were observed in $18 / 35,13 / 35,1 / 35,1 / 35$, and $2 / 35$ broiler breeder hens. The 13/35 group (Genotype B) had a $2.4 \mathrm{~kb}$ band which was not present in any other group. A $3.4 \mathrm{~kb}$ band was observed in 34 birds, as was a $4.25 \mathrm{~kb}$ band. The $5.4 \mathrm{~kb}$ band was present in two birds. The largest fragment seen, a $7.5 \mathrm{~kb}$ band, was observed in only one bird. Since the majority of birds fell into the 18/35 and 13/35 groups, the other four hens were deleted from the statistical analysis, to leave a pure comparison between Genotypes A and B.

Egg production during a 45-week period, when all eggs were set, was different between the two groups. Hens with the $2.4 \mathrm{~kb}$ band laid significantly fewer eggs than broiler breeder hens without the $2.4 \mathrm{~kb}$ band (Genotype A). Hens with Genotypes A and B laid 0.365 and 0.260 eggs per day respectively. Briles and Allen (1961) also observed lower rates of lay in B homozygous white leghorns and New Hampshires. Both crossbred and inbred white leghorns had similar associations (Allen and Gilmour, 1962; Nordskog et al., 1973). Zhu et al. (1995) found that selection of turkey lines for egg production resulted in changes in MHC haplotypes observed. The present experiment showed that an association of egg production with the MHC exists in the broiler breeder hen.

Total egg production, average egg mass, percent fertility, and percent hatchability of fertile eggs were not different in this study. The lack of differences for these traits in the current study is not unusual, in relation to the existing body of literature. Although total egg production was relatively higher for the hens without the $2.4 \mathrm{~kb}$ band $(197 \pm 12 \mathrm{vs} .169 \pm 14)$, the values were not significantly different. This may represent a biological difference which is not significant due to sample size. Egg mass was found to be affected by MHC haplotype 
in three studies. Kim et al. (1989) demonstrated this in inbred white leghorns. Abplanalp et al. (1992) and Sato et al. (1992) demonstrated the effect in congenic white leghorns, differing only at the MHC. No effect of the B complex on fertility has been shown to date. Hatchability was higher for chicks from heterozygous than from homozygous sires (Briles and Drueger, 1955). Abplanalp et al. (1992) observed effects of the B complex on hatchability in 11 lines of congenic white leghorns.

In conclusion, this study establishes the fact that the Class II genes of the MHC are polymorphic in broiler breeder hens. Also, an effect of the MHC on reproduction of broiler breeders was observed during a 45-week hatching period, as evidenced by a higher number of eggs produced by the Genotype A group of hens, lacking a specific restriction fragment of $2.4 \mathrm{~kb}$. The polymorphisms observed here must be characterized further in order to effectively relate the present data to previously published studies. However, the possiblity of utilizing the MHC as a tool in broiler breeder selection seems achievable. 


\section{APPENDIX I}

\section{DNA Isolation}

1. Store $50 \mu \mathrm{L}$ aliquots of blood in $1.5 \mathrm{~mL}$ microcentrifuge tubes containing $100 \mu \mathrm{L} 1 \mathrm{X}$ $\mathrm{SSC}$ at $-20^{\circ} \mathrm{C}$.

2. Thaw aliquot quickly at $37^{\circ} \mathrm{C}$.

3. Add $400 \mu \mathrm{L} 12 \mathrm{X}$ SSC and mix gently.

4. Add SDS to $1 \%$ and mix gently for $10 \mathrm{~min}$ on a reciprocal shaker.

5. Add $500 \mu \mathrm{L}$ phenol/chloroform/isoamyl alcohol (25:24:1) and mix 20 min on shaker. Pipette sample until it is homogenized.

6. Centrifuge $5-15 \mathrm{~min}$ at $14000 \mathrm{X} \mathrm{G}$.

7. Pipette supernatant to a sterile tube, avoiding the interphase.

8. Repeat phenol/chloroform/isoamyl alcohol extraction.

9. Add 2.5 volumes of $100 \%$ ethanol. Precipitate DNA by inverting the tube repeatedly. Carefully discard the ethanol.

10. Add $400 \mu \mathrm{L} \mathrm{H}_{2} \mathrm{O}$ and allow pellet to dissolve.

11. Add 2.5 volumes of $100 \%$ ethanol. Precipitate DNA by inverting the tube.

12. Discard the ethanol. Wash the pellet with $500 \mu \mathrm{L} 70 \%$ ethanol.

13. (optional) Dry the pellet for $5 \mathrm{~min}$, dissolve it in $400 \mu \mathrm{L} \mathrm{H} \mathrm{H}_{2} \mathrm{O}$, and repeat the ethanol precipitations.

14. Invert the tube over Whatman paper to dry the DNA.

15. Dissolve the DNA in $100-200 \mu \mathrm{L}$ of TE buffer.

NOTE: Always wear gloves when working with phenol.

When using fresh blood, begin at step 3 with the addition of $500 \mu \mathrm{L} 10 \mathrm{X}$ SSC. 


\section{LITERATURE CITED}

Abplanalp, H., K. Sato, D. Napolitano, and J. Reid, 1992. Reproductive performance of inbred congenic leghorns carrying different haplotypes for the major histocompatibility complex. Poultry Sci. 71:9-17.

Allen, C. P. and D. G. Gilmour, 1962. The B blood group system of chickens. III. The effects of two heterozygous genotypes on the survival and egg production of multiple crosses. Genetics 47:1711-1718.

Allen, C. P., 1962. The effect of parental $B$ locus genotypes on multiple cross performance in chickens. Annals New York Academy of Sciences. 97:184-193.

Anderson, K. S. and P. Cresswell, 1994. A role for calnexin (IP90) in the assembly of class II MHC molecules. The EMBO Journal. 13:675-682.

Andersson, L., C. Lundberg, L. Rask, B. Gissel-Nielsen, and M. Simonsen, 1987. Analysis of class II genes of the chicken MHC $(B)$ by use of human DNA probes. Immunogenetics. 26:79-84.

Bacon, L. D. , 1987. Influence of the major histocompatibility complex on disease resistance and productivity. Poultry Sci. 66:802-811. 
Bloom, S. E., W. E. Briles, R. W. Briles, M. E. Delany and R. R. Dietert, 1987. Chromosomal localization of the major histocompatibility $(B)$ complex (MHC) and its expression in chickens aneuploid for the major histocompatibility complex/ribosomal deoxyribonucleic acid microchromosome. Poultry Sci. 66:782-789.

Bloom, S. and L. Bacon, 1985. Linkage of the major histocompatibility (B) complex and the nucleolar organizer in the chicken. J. Heredity. 76:146-154.

Boa-Amponsem, K., W. E. Briles, R. W. Briles, E. A. Dunnington, and P. B. Siegel. 1992. Selection for body weight at eight weeks of age. 20. Production traits and the $B$ and $C$ alloantigen systems. Poultry Sci. 71:1583-1589.

Bourlet, Y., G. Béhar, F. Guillemot, N. Fréchin, A. Billault, A.-M. Chaussé, R. Zoorob, and C. Auffray, 1988. Isolation of chicken major histocompatibility complex class II (B-L) $B$ chain sequences: comparison with mammalian $B$ chains and expression in lymphoid organs. The EMBO Journal. 7:1031-1039.

Briles, W. E. 1953. Abstract. The effect of heterozygosity of the blood group locus $B$ on hatchability in three leghorn inbred lines. Proceedings of the Association of Southern Agricultural Workers, page 184.

Briles, W. E. 1954a. Abstract. Further data on the effect of the blood group locus $B$ on 
hatchability of inbred lines. Proceedings of the Association of Southern Agricultural Workers, page 167.

Briles, W. E. 1954b. Abstract. Evidence for overdominance of the $B$ blood group alleles in the chicken. Genetics. 39:961-962.

Briles, W. E. 1962. Additional blood group systems in the chicken. Annals New York Academy of Sciences. 97:172-183.

Briles, W. E. 1964. Current status of blood groups in domestic birds. Zeitschrift für Tierzüchtung und Züchtungsbiologie. 79:371-379.

Briles, W. E. 1984. Early chicken blood group investigations. Immunogenetics. 20:217226.

Briles, W. E., W. H. McGibbon, and M. R. Irwin, 1950. On multiple alleles effecting cellular antigens in the chicken. Genetics 35:633-652.

Briles, W. E., L. W. Johnson, and M. J. Garber. 1953. Abstract. The effect of heterozygosity at the blood group locus B on weights at 9 weeks at age in related inbred lines of white leghorns. Poultry Sci. 32:890. 
Briles, W. E. and W. F. Krueger. 1955. Abstract. The effect of parental $B$ blood group genotypes on hatchability and livability in leghorn inbred lines. Poultry Sci. 34:1182.

Briles, W. E. and C. P. Allen, 1961. The B blood group system of chickens. II. The effects of genotype on livability and egg production in seven commercial inbred lines. Genetics 46:1273-1293.

Briles, W. E. and R. W. Briles. 1977. Some recent recombinants at the $B$ locus. Avian Immunology. 221-225.

Briles, W. E. and R. W. Briles, 1987. Genetics and classification of major histocompatibility complex antigens of the chicken. Poultry Sci. 66:776-781.

Briles, W. E., R. M. Goto, C. Auffray, and M. M. Miller, 1993. A polymorphic system related to but genetically independent of the chicken major histocompatibility complex. Immunogenetics. 37:408-414.

Brown, J. L. and A. Eklund, 1994. Kin recognition and the major histocompatibility complex: and integrative review. Am. Nat. 143:170-176.

Chakrabarti, A., J. Matko, N. A. Rahman, B. G. Barisas, and M. Edidin. 1992. Selfassociation of class I major histocompatibility complex molecules in liposome and cell surface 
membranes. Biochemistry. 31:7182-7189.

Chaussé, A.-M., F. Coudert, G. Dambrine, F. Guillemot, M. M. Miller, and C. Auffray, 1989. Molecular genotyping of four chicken $B$-complex haplotypes with B- $\mathrm{L}_{B}$, B-F, and B-G probes. Immunogenetics. 29:127-130.

Chen, Y. and S. J. Lamont, 1992. Major histocompatibility complex class I restriction fragment length polymorphism analysis in highly inbred chicken lines and lines selected for major histocompatiblity complex and immunoglobulin production. Poultry Sci. 71:999-1006.

Collins, W. M., W. E. Briles, R. M. Zsigray, W. R. Dunlop, A. C. Corbett, K. K. Clark, J. L. Marks, and T. P. McGrail, 1977. The $B$ Locus (MHC) in the chicken: association with the fate of RSV-induced tumors.

Counce, S., P. Smith, R. Barth, G. D. Snell, 1956. Strong and weak histocompatibility gene differences in mice and their role in the rejection of homografts of tumors and skin. Annals of Surgery. 144:198-204.

Danliczyk, U. G. and T. L. Delovitch, 1994. $B_{2}$-Microglobulin induces a conformational change in an MHC class I $\mathrm{H}$ chain that occurs intracellulary and is maintained at the cell surface. J. Immunology. 153:3533-3542. 
Dausset, J. 1958, Iso-leuco-anticorps. Acta Haematalogica. 20:156-166.

Dietert, R. R., R. L. Taylor, Jr., and M. F. Dietert, 1991. Biological function of the chicken major histocompatibility complex. Crit. Rev. Poultry Biol. 3:111-129.

Dietert, R. R., 1987. Introduction: the major histocompatibility complex as a communication gene complex. Poultry Sci. 66:774-775.

Dominguez-Steglich, M., C. Auffray, and M. Schmid. 1991. Linkage of the chicken MHC to the nucleolus organizer region visualized using non-istopic in situ hybridization. Journal of Heredity. 82:503-505.

Due, C., M. Simonsen, and L. Olsson. 1986. The major histocompatibility complex class I heavy chain as a structural subunit of the human cell membrane insulin receptor: implications for the range of biological functions of histocompatibility antigens. Proc. Natl. Acad. Sci. USA. 83:6007-6011.

Dunnington, E. A., A. S. Larsen, N. P. O'Sullivan, and P. B. Siegel, 1992. Growth and egg production traits in chickens as influenced by major histocompatibility types and background genomes. J. Anim. Breed. Genet. 109:188-196.

Edidin, M. 1988. Function by association? MHC antigens and membrane receptor 
complexes. Immunology Today. 9:218-219.

Emara, M. G., K. E. Nestor, D. N. Foster, and S. J. Lamont, 1992. The turkey major histocompatibility complex: identification of class II genotypes by restriction fragment length polymorphism analysis of deoxyribonucleic acid. Poultry Sci. 71:2083-2089.

Gavora, J. S., M. Simonsen, J. L. Spencer, R. W. Fairfull, and R. S. Gowe, 1986. Changes in the frequency of major histocompatibility haplotypes in chickens under selection for both high egg production and resistance to Marek's disease. J. Anim. Breeding. Genet. 103:218226.

Gavora, J. S. and J. L. Spencer, 1983. Breeding for immune responsivenesss and disease resistance. Animal Blood Groups and Biochemical Genetics. 14:159-180.

Germain, R. M. and D. H. Margulies, 1993. The biochemistry and cell biology of antigen processing and presentation. Annu. Rev. Immunol. 11:403-450.

Gibson, T. and P. B. Medawar. 1943. The fate of skin homografts in man. J. Anatomy. 77:299-308.

Gill, T. J. III, S. Siew, and H. W. Kunz, 1983. Major histocompatibility complex (MHC)linked genes affecting development. J. Exp. Zoology. 228:325-345. 
Gilmour, D. G., 1959. Segregation of genes determining red cell antigens at high levels of inbreeding in chickens. Genetics 44:14-33.

Gilmour, D. G., 1960. Blood groups in chickens. British Poultry Sci. 1:75-100.

Gilmour, D. G. and J. R. Morton, 1970. Association of genetic polymorphisms with embryonic mortality in the chicken. II. The B blood-group system and the pure and crossbred progeny of two populations. Genet. Res., Camb. 15:265-284.

Gilmour, D. G., 1962. Current status of blood groups in chickens. Annals New York Acad. Sci. 97:166-172.

Gorer, P. A., 1936a. The detection of a hereditary antigenic difference in the blood of mice by means of human group A serum. J. Genetics. 32:17-31.

Gorer, P. A., 1936b. The detection of antigenic differences in mouse erythrocytes by the employment of immune sera. British Journal of Experimental Pathology. 17:42-50.

Gorer, P. A., 1937a. Further studies on antigenic differences in mouse erythrocytes. British Journal of Experimental Pathology. 18:31-36.

Gorer, P. A., 1937b. The genetic and antigenic basis of tumour transplantation. Journal of 
Pathology and Bacteriology. 44:691-697.

Gorer, P. A., 1938. The antigenic basis of tumour transplantation. Journal of Pathology and Bacteriology. 47:231-252.

Gorer, P. A., S. Lyman, and G. D. Snell. 1948. Studies on the genetic and antigenic basis of tumour transplantation. Linkage between a histocompatibility gene and 'fused' in mice. Proc. Royal Soc. of London. Series B. 135:499-505.

Guillemot, F., A. Billault, O. Pourquie, G. Behar, A.-M. Chausse, R. Zoorob, G. Kreibich, and C. Auffray. 1988. A molecular map of the chicken major histocompatibility complex: the class II $\beta$ genes are closely linked to the class I genes and the nucleolar organizer. EMBO Journal 7:2775-2785.

Guillemot, F., P. Turmel, D. Charron, N. Le Douarin, and C. Auffray, 1986. Structure, biosynthesis, and polymorphism of chicken MHC class II (B-L) antigens and associated molecules. J. Immunol. 137:1251-1257.

Guillemot, F., J.F. Kaufman, K. Skjoedt, and C. Auffray. 1989. The major histocompatibility complex in the chicken. Trends in Genetics 5:300-304.

Guillemot, F. and C. Auffray. 1989. Molecular biology of the chicken major 
histocompatibility complex. Critical Reviews in Poultry Biology 2:255-275.

Hála, K., A.-M. Chaussé, Y. Bourlet, O. Lassial, V. Hasler, and C. Auffray. 1988. Attempt to detect recombination between $B-F$ and $B-L$ genes within the chicken $B$ complex by serological typing, in vitro MLR, and RFLP analysis. Immunogenetics 28:433-438.

Hansen, T.H., B.M. Carreno, and D.H. Sachs. 1993. The major histocompatiblity complex. In: Paul, W.E., ed. Fundamental Immunology, Third edition. Raven Press, Ltd., New York, NY.

Hashimoto, K, T. Nakanishi, and Y. Kurosawa, 1990. Isolation of carp genes encoding major histocompatibility complex antigens. Proc. Natl. Acad. Sci. USA. 87:6863-6867.

Heath, E. M. M. D. Hopf, and R. M. Shuman, 1994. Abstract. Developing DNA-based MHC typing reagents for commercial white leghorn and broiler strains. Poultry Sci. 73(Suppl. 1):5.

Hemendinger, R. A., J. R. Putnam, and S. E. Bloom. 1992. MHC dosage effects on primary immune organ development in the chicken. Developmental and Comparative Immunology. $16: 175-186$.

Hepkema, B. G., M. G. J. Tilanus, H. J. Blankert, G. A. A. Albers, M. C. GrosfeldStulemeyer, and E. J. Hensen. 1993. A high recombination frequency within the chicken 
major histocompatiblity (B) complex. Animal Genetics. 24:389-391. short communication.

Hordvik, I., U. Grimholt, V. M. Fosse, O. Lie, and C. Endresen, 1993. Cloning and sequence analysis of cDNAs encoding the MHC class II beta chain in Atlantic salmon (Salmo salar). Immunogenetics. 37:437-441.

Juul-Madsen, H. R., J. Glamann, H. O. Madsen, and M. Simonsen, 1992. MHC class II betachain expression in the rainbow trout. Scand. J. Immunol. 35:687-694.

Kasahara, M., M. Vazquez, K. Sato, E. C. McKinney, and M. F. Flajnik, 1992. Evolution of the major histocompatibility complex: Isolation of class II $A$ cDNA clones from the cartilaginous fish. Proc. Natl. Acad. Sci. USA. 89:6688-6692.

Kaufman, J. and J. Salomonsen, 1992. B-G: we know what it is, but what does it do? Immunology Today. 13:1-3.

Kenny, N., N. A. Rahman, B. G. Barisas, and D. A. Roess. 1993. Class I major histocompatibility complex antigens are not associated with the LH/CG receptor on ovine luteal cells. Biochimica et Biophysica Acta. 1220:94-100.

Kim, C.D., S.J. Lamont, and M.F. Rothschild. 1989. Associations of major histocompatibility complex haplotypes with body weight and egg production traits in S1 
White Leghorn chickens. Poultry Science 68:464-469.

Kroemer, G., A. Bernot, G. Béhar, A.-M. Chaussé, L.-N. Gastinel, F. Guillemot, I. Park, P. Thoraval, R. Zoorob, and C. Auffray, 1990. Molecular genetics of the chicken MHC: current status and evolutionary aspects. Immunological Reviews. No. 113:119-145.

Kronenberg, M., R. Brines, and J. Kaufman, 1994. MHC evolution: a long term investment in defense. Immunology Today. 15:4-6.

Lamont, S.J., B.M. Gerndt, C.M. Warner, and L.D. Bacon. 1990. Analysis of restriction fragment length polymorphisms of the major histocompatibility complex of $151_{5}-B$-congenic chicken lines. Poultry Science 69:1195-1203.

Lamont, S.J. and R.R. Dietert. 1990. Immunogenetics. In: Crawford, R.D., editor. Poultry Breeding and Genetics. Elsevier Science Publishers, Amsterdam, The Netherlands.

Lamont, S. J. and L. D. Bacon, 1990. Analysis of restriction fragment length polymorphisms of the major histocompatibility complex of $151_{5}-B$-congenic chicken lines. Poultry Sci. 69:1195-1203.

Lamont, S. J., 1989. The chicken major histocompatibility complex in disease resistance and poultry breeding. J. Dairy Sci. 72:1328-1333. 
Lamont, S. J., 1993. The major histocompatibility complex in chickens. Pages 185-203. in: Manipulation of the avian genome. R. J. Etches and A. M. Verrinder Gibbins, ed. CRC Press, Boca Raton, FL.

Lamont, S. J., Y. Chen, H. J. M. Aarts, M. C. Van Der Hulst-Van Arkel, G. Beuving, and F. R. Leenstra, 1992. Endogenous viral genes in thirteen highly inbred chicken lines and in lines selected for immune response traits. Poultry Sci. 71:530-538.

Lamont, S.J., Y.-H. Hou, B.M. Young, and A.W. Nordskog. 1987. Research note: differences in major histocompatibility complex gene frequencies associated with feed efficiency and laying performance. Poultry Science 66:1064-1066.

Lamont, S. J., 1991. Immunogenetics and the major histocompatibility complex. Veterinary Immunology and Immunopathology. 30:121-127.

Lamont, S.J., C.M. Warner, and A.W. Nordskog. 1987. Molecular analysis of the chicken major histocompatibility complex gene and gene products. Poultry Science 66:819-824.

Landesman, E., Z. Uni, and E. D. Heller, 1993. Designation by restriction fragment length polymorphism of major histocompatibility complex IV haplotypes in meat-type chickens. Animal Genetics. 24:349-354. 
Lerner, S.P. and C.E. Finch. 1991. The major histocompatibility complex and reproductive functions. Endocrine Reviews 12:78-90.

Levin, I., L. Santangelo, H. Cheng, L. B. Crittenden, and J. B. Dodgson, 1994. An autosoman genetic linkage map of the chicken. J. Hered. 85:79-85.

Longenecker, B. M. and T. R. Mosmann, 1981. Structure and properties of the major histocompatibility complex of the chicken. Speculations on the advantages and evolution of polymorphism. Immunogenetics. 13:1-23.

Loss, G. E. Jr. and A. J. Sant, 1993. Invariant chain retains MHC class II molecules in the endocytic pathway. J. Immunol. 150:3187-3197.

Lunden, A., I. Edfors-Lilja, K. Johansson, L.-E. Liljedahl, and M. Simonsen. 1993. Associations between major histocompatibility complex genes and production traits in White Leghorns. Poultry Science 72:989-999.

Martin, A., E.A. Dunnington, W.B. Gross, W.E. Briles, R.W. Briles, and P.B. Siegel. 1990. Production traits and alloantigen systems in lines of chickens selected for high or low antibody responses to sheep erythrocytes. Poultry Science 69:871-878.

Medawar, P. B. 1944. The behaviour and fate of skin autografts and skin homografts in 
rabbits. J. Anatomy. 78:176-199.

Miller, M. M., H. Abplanalp, and R. Goto, 1988. Genotyping chickens for the $B-G$ subregion of the major histocompatibility complex using restriction fragment length polymorphisms. Immunogenetics. 28:374-379.

Miller, M. M., R. Goto, A. Bernot, R. Zoorob, C. Auffray, M. Bumstead, and W. E. Briles. 1994a. Two Mhc class I and two $M h c$ class II genes map to the chicken $R f p-y$ system outside the $B$ complex. Proc. Natl. Acad. Sci. USA. 91:4397-4401.

Miller, M. M., R. Goto, R. Zoorob, C. Auffray, and W. E. Briles. 1994b. Regions of homology shared by $R f p-Y$ and major histocompatibility $B$ complex genes. Immunogenetics. 39:71-73.

Momburg, F., J. Roelse, G. J. Hammerling, and J. J. Neefjes, 1994. Peptide size selection by the major histocompatibility complex-encoded peptide transporter. J. Exp. Med. 179:16131623.

Morton, J. R., D. G. Gilmour, E. M. McDermid, and A. L. Ogden, 1965. Association of blood-group and protein polymorphisms with embryonic mortality in the chicken. Genetics. 51:97-107. 
Neefjes, J. J. and H. L. Ploegh, 1992. Intracellular transport of MHC class II molecules. Immunology Today. 13:179-184.

Nijenhuis, M., J. Calafat, K. C. Kuijpers, H. Janssen, M. de Haas, T. W. Nordeng, O. Bakke, and J. J. Neefjes, 1994. Targeting major histocompatibility complex class II molecules to the cell surface by invariant chain allows antigen presentation upon recycling. Eur. J. Immunol. 24:873-883.

Nijenhuis, M. and J. Neefjes, 1994. Early events in the assembly of major histocompatibility complex class II heterotrimers from their free subunits. Eur. J. Immunol. 24:247-256.

Nordskog, A. W., I. Y. Pevzner, and S. J. Lamont, 1987. Subregions and functions of the chicken major histocompatibility complex. Poultry Sci. 66:790-794.

Nordskog, A.W., W.A. Rishell, and D.M. Briggs. 1973. Influence of B locus blood groups on adult mortality and egg production in the White Leghorn chicken. Genetics 75:181-189.

Ohno, S., 1961. Sex chromosomes and microchromosomes of Gallus domesticus. Chromosoma 11:484-498.

Owen, J.J.T., 1965. Karyotype studies on Gallus domesticus. Chromosoma 16:601-608. 
Pharr, G. T., H. D. Hunt, L. D. Bacon, and J. B. Dodgson, 1993. Identification of class II major histocompatibility complex polymorphisms predicted to be important in peptide presentation. Poultry Sci. 72:1312-1317.

Philpott, C. J., N. A. Rahman, T. R. Londo, and D. A. Roess, 1992. Abstract. Rotational dynamics of luteinizing hormone receptors and MHC I antigen on murine leydig cells. Biology of Reproduction (Suppl. 1). 63.

Philpott, C. J., N. A. Rahman, N. Kenny, T. R. Londo, R. M. Young, B. G. Barisas, D. A. Roess, 1995. Rotational dynamics of luteinizing hormone receptors and MHC class I antigens on murine leydig cells. Biochimica et Biophysica Acta. 1235:62-68.

Pink, J. R. L., W. Droege, K. Hála, V. C. Miggiano, and A. Ziegler, 1977. A three-locus model for the chicken major histocompatibility complex. Immunogenetics. 5:203-216.

Plachy, J., J. R. L. Pink, and K. Hála, 1992. Biology of the chicken MHC (B complex). Critical Reviews in Immunol. 12:47-79.

Podesta, E. J., A. R. Solano, and M. L. Sanchez, 1986. Luteinizing hormone triggers two opposite regulatory pathways through an initial common event, receptor aggregation. Endocrinology. 119:989-997. 
Roess, D. A., N. Kenny, N. A. Rahman, and B. G. Barisas, 1990a. (Abstract) MHC class I antigen does not associate with the luteinizing hormone receptor on ovine luteal cells. Biology of Reproduction. 42(Suppl. 1):136.

Roess, D. A., N. Kenny, N. A. Rahman, and B. G. Barisas, 1990b. (Abstract) Differences in rotational diffusion of luteinizing hormone receptors on murine leydig cells when occupied by LH versus hCG. Endocrine Society Abstracts. \#1344.

Sambrook, J., E.F. Fritsch, and T. Maniatis, 1989. Molecular cloning: a laboratory manual. second edition. Cold Spring Harbor Laboratory Press. Plainview, New York.

Sato, K., Abplanalp, D. Napolitano, and J. Reid, 1992. Effects of heterozygosity of major histocompatibility complex haplotypes on performance of Leghorn hens sharing a common inbred background. Poultry Science 71:18-26.

Sato, K., M. F. Flajnik, L. Du Pasquier, M. Katagiri, and M. Kasahara, 1993. Evolution of the MHC: Isolation of class II B-chain cDNA clones from the amphibian Xenopus laevis. J. Immunol. 150:2831-2843.

Schierman, L.W. and A.W. Nordskog, 1961. Relationship of blood type to histocompatibility in chickens. Science 134:1008-1009. 
Schierman, L.W. and W.M. Collins, 1987. Influence of the major histocompatibility complex on tumor regression and immunity in chickens. Poultry Science 66:812-818.

Shiina, T., A. Ando, T. Imanishi, H. Kawata, K. Hanzawa, T. Gojobori, H. Inoko, and S. Watanabe, 1995. Isolation and characterization of cDNA clones for Japanese quail (Coturnix japonica) major histocompatibility complex (MhcCoja) class I molecules. Immunogenetics. 42:213-216.

Shoskes, D. A. and K. J. Wood, 1994. Indirect presentation of MHC antigens in transplantation. Immunology Today. 15:32-38.

Shuman, R.M., E.M. Heath, G.T. Pharr, H.D. Hunt, J.E. Fulton, and L.D. Bacon, 1993. Abstract. Development of an MHC typing test using DNA amplification and oligonucleotide probes. Poultry Science 72(Suppl. 1):10.

Siegel, P.B., A.S. Larsen, C.T. Larsen, and E.A. Dunnington, 1993. Research note: resistance of chickens to an outbreak of necrotic enteritis as influenced by major histocompatibility genotype and background genome. Poultry Science 72:1189-1191.

Simonsen, M., 1986. The relationship of egg production in the chicken to its major histocompatibility complex. Pages 367-374 in: Immunological approaches to contraception and promotion of fertility. G. P. Talwar, ed. Plenum Press, New York, NY. 
Simonsen, M., N. Kolstad, I. Edfors-Lilja, L.-E. Liljedahl, and P. Sorensen, 1982. Major histocompatibility genes in egg-laying hens. American J. of Reproductive Immunology. 2:148152.

Snell, G. D., 1948. Methods for the study of histocompatibility genes. J. of Genetics. 49:87103.

Solano, A. R., M. L. Sanchez, M. L. Sardanons, L. Dada, and E. J. Podesta, 1988. Luteinizing hormone triggers a molecular association between its receptor and the major histocompatibility complex class I antigen to produce cell activation. Endocrinology. 122:2080-2083.

Soller, M. and J.S. Beckmann, 1986. Restriction fragment length polymorphisms in poultry breeding. Poultry Science 65:1474-1488.

Sung, A. M., A. W. Nordskog, S. J. Lamont, and C. M. Warner, 1993. Isolation and characterization of cDNA clones for chicken major histocompatibility complex class II molecules. Animal Genetics. 24:227-233.

Takeuchi, H., F. Figueroa, C. O'hUigin, and J. Klein, 1995. Cloning and characterization of class I Mhc genes of the zebrafish, Brachydanio rerio. Immunogenetics. 42:77-84. 
Ulmer, J. B., J. J. Donnelly, and M. A. Liu, 1994. Presentation of an exogenous antigen by major histocompatibility complex class I molecules. Eur. J. Immunol. 24:1590-1596.

Uni, Z., M. Gutman, G. Leitner, E. Landesman, D. Heller, and A. Cahaner, 1993. Major histocompatibility complex class IV restriction fragment polymorphism markers in replicated meat-type chicken lines divergently selected for high or low early immune response. Poultry Science 72:1823-1831.

Vainio, O., C. Koch, and A. Toivanen, 1984. B-L antigens (class II) of the chicken major histocompatibility complex control T-B cell interaction. Immunogenetics. 19:131-140.

Vainio, O., P., Toivanen, and A. Toivanen, 1987. Major histocompatibility complex and cell cooperation. Poultry Sci. 66:795-801.

Vitetta, E. S., J. W. Uhr, J. Klein, F. Pazderka, E. J. Moticka, R. F. Ruth, and J. D. Capra, 1977. Homology of (murine) H-2 and (human) HLA with a chicken histocompatibility antigen. Nature. 270:535-536.

Wade, W. F., J. H. Freed, and M. Edidin, 1989. Translational diffusion of class II major histocompatibility complex molecules is constrained by their cytoplasmic domains. The Journal of Cell Biology. 109:3325-3331. 
Warner, C., B. Gerndt, Y. Xu, Y. Bourlet, C. Auffray, S. Lamont, and A. Nordskog, 1989. Restriction fragment length polymorphism analysis of major histocompatibility complex class II genes from inbred chicken lines. Animal Genetics. 20:225-231.

Warner, C. M., 1986. Genetic manipulation of the major histocompatibility complex. J. Anim. Sci. 63:279-287.

Wittzell, H., T. von Schantz, R. Zoorob, and C. Auffray, 1994. Molecular characterization of three $M h c$ class II $B$ haplotypes in the ring-necked pheasant. Immunogenetics. 39:395-403.

Wittzell, H., T. von Schantz, R. Zoorob, C. Auffray, 1995. Rfp-Y-like sequences assort independently of pheasant Mhc genes. Immunogenetics. 42:68-71.

Wood, G. W., 1994. Is restricted antigen presentation the explanation for fetal allograft survival? Immunology Today. 15:15-18.

Xu, Y., J. Pitcovski, L. Peterson, C. Auffray, Y. Bourlet, B.M. Gerndt, A.W. Norkskog, S.J. Lamont, and C.M. Warner, 1989. Isolation and characterization of three class II MHC genomic clones from the chicken. Journal of Immunology 142:2122-2132.

Ziegler, A. and R. Pink, 1976. Chemical properties of two antigens controlled by the major 
histocompatibility complex of the chicken. J. Biol. Chem. 251:5391-5396.

Ziegler, A. and J. R. L. Pink, 1975. Characterization of major histocompatibility (B) antigens of the chicken. Transplantation. 20:523-526. Brief Communication.

Zoorob, R., G. Béhar, G. Kroemer, and C. Auffray, 1990. Organization of a functional chicken class II $B$ gene. Immunogenetics. 31:179-187. 
Name

Parents

Date of Birth

Place of Birth

Schools Attended:

Lake Butler Elementary School

Lake Butler, Florida

Lake Butler Middle School

Lake Butler, Florida

Union County High School

Lake Butler, Florida

Lake City Community College

Lake City, Florida

Auburn University

Auburn, Alabama

West Virginia University

Morgantown, West Virginia

Auburn University

Auburn, Alabama.
Becky Jean Tarleton

Allen Leo Tarleton

Elaine Barnes Tarleton

March 30, 1970

Gainesville, Florida
1975-1978

1979-1983

1984-1988

1986

$1988-1992$

1992-1995

1995-present

\section{Degree Received:}

Bachelor of Science, Animal and Dairy Science Auburn University 